\title{
FEASIBILITY OF VERMICOMPOSTING DEWATERED SLUDGE FROM PAPER MILLS USING PERIONYXEXCAVATUS
}

\author{
PUSPANJALI SONOWAL ${ }^{1}$, DHAMODHARAN K ${ }^{1}$, \\ MEENA KHWAIRKPAM ${ }^{2}$, and AJAY S. KALAMDHAD ${ }^{1, *}$ \\ ${ }^{1}$ Department of Civil Engineering, Indian Institute of Technology Guwahati (IITG), Guwahati, India \\ 2 Department of Civil Engineering, Malaviya National Institute of Technology (MNIT) Jaipur, India \\ * Corresponding author: kalamdhad@gmail.com
}

\begin{abstract}
India has a large network of pulp and paper mills of varying capacity. On an industrial scale the sludge from paper and pulp mills is disposed of either as landfill or incinerated. Both methods result in the loss of a valuable resource and have obvious environmental and economic disadvantages. The solid waste from pulp and paper mills is a source of organic matter and its proper disposal and management is the responsibility of the industry. As composting/vermicomposting could be used to transform this waste trials were carried out to determine the feasibility of converting dewatered sludge (DS) into a value added end product using an earthworm, Perionyx excavatus. The vermicomposting of the waste resulted in an increase in its electrical conductivity (EC), ash content, total nitrogen (TN), total phosphorous (TP) and available phosphorous (AP), respectively, and a decrease in total organic carbon (TOC), biochemical oxygen demand (BOD), chemical oxygen demand (COD), oxygen uptake rate (OUR) and evolution of carbon dioxide $\left(\mathrm{CO}_{2}\right)$. Overall, the best treatment was T5 in which there was a $76.1 \%$ increase in TP, 58.7\% in TN, $74.5 \%$ decrease in TOC, and a reduction of 6.7 fold in the production of $\mathrm{CO}_{2}$ and 10.7 fold in BOD, respectively. Our trials demonstrate that vermicomposting using an epigeic earthworm, Perionyx excavatus, is an alternate and environmentally safe way of recycling paper mill sludge if it is mixed with an appropriate amount of cow dung and food processing waste. Overall T5 was the best combination of paper mill sludge and waste for vermicomposting followed by $\mathrm{T} 3, \mathrm{~T} 2, \mathrm{~T} 4$ and $\mathrm{T} 1$, respectively.
\end{abstract}

Keywords: $\mathrm{C} / \mathrm{N}$, vermicompost, food processing waste, cow dung

\section{Introduction}

Disposal of industrial sludge using environmentally acceptable means poses a very great challenge worldwide. It has been suggested that earthworms be used for this purpose (Elvira et al. 1998) and the process has been termed vermistabilization (Neuhauser et al. 1988). A considerable amount of work has been done on the composting of various organic materials using earthworms, which has revealed that epigeic earthworms can hasten the composting process to a significant extent and produce a better quality of compost than that produced by traditional composting methods (Ghosh et al. 1999). Perionyx excavatus is an epigeic species of earthworm, which lives in organic waste and could be potentially used to convert organic waste into a valuable end product. P. excavatus is known to be good at converting organic waste into high-value vermicompost, which can be used as a medium for growing plants (Kale et al. 1982; Suthar 2006). Nevertheless, most of the vermiculture experiments using $P$. excavatus were done using animal dung e.g. cow dung (Kale et al. 1982; Reinecke et al. 1992; Edwards et al. 1998), sheep dung (Kale et al. 1982), biogas sludge (Kale et al. 1982; Edwards et al. 1998), poultry manure (Kale et al. 1982), pig solids (Edwards et al. 1998), horse solids (Edwards et al. 1998) and turkey waste (Edwards et al. 1998). The potential of $P$. excavatus for processing other wastes, namely vegetable waste (Singh et al. 2005) and water hyacinth (Eichhornia crassipes) (Gajalakshmi et al. 2001), however, has also been tested. Vermicomposting is not only rapid, easily controllable, cost effective, energy saving and a zero discharge process, but also efficiently accomplishes the recycling of organic substances and nutrients. Transformation of organic industrial waste by vermicomposting can be the cheapest and safest way of disposing of it without polluting the environment (Elvira et al. 1996; Kaushik and Garg 2003) and recovering vermi fertilizer and animal protein (Chaudhuri 2005). Moreover, vermicompost is fragmented and microbially active due to humification (Edwards and Bohlen 1996; Maboeta and Rensburg 2003) and contains important plant nutrients in forms that are soluble and more easily available to plants than those in ordinary compost (Ndegwa and Thompson 2001). Therefore, the objective of this study was to test the feasibility of using the earthworm P. excavatus to stabilize dewatered sludge (DS) from pulp and paper mills mixed with cow dung (CD) and food processing waste $(\mathrm{FPW})$ in different ratios.

\section{Materials and methods}

\section{Earthworm cultures}

The species of earthworm chosen for the compositing experiment was Perionyx excavatus. This earthworm was obtained from Central Plantation Crops Research Institute (CPCRI), Indian Council of Agricultural Research, Guwahati, India. For rearing the earthworm cultures, hopper bottom Perspex bins, $450 \mathrm{~mm} \times 300 \mathrm{~mm} \times 450 \mathrm{~mm}$ 
in size, were fabricated in the laboratory. For aeration and drainage purposes 16 holes of $10 \mathrm{~mm}$ diameter were drilled along the longer sides and 16 in the bottom, respectively. Hoppers were used to collect leachate (if any). Before the addition of the culture medium and earthworms, bedding was prepared from partially degraded chopped hay (about $50 \mathrm{~mm}$ ), cow dung, banana pulp (chopped about $50 \mathrm{~mm}$ ) and tree leaves. This bedding was watered to keep it moist to enable the worms to breathe. Then the earthworms were added along with partially degraded cow dung as a source of food for the earthworms.

\section{Compost material}

Dewatered sludge (DS), cow dung (CD) and food processing waste (FPW) were mixed in different proportions. DS was collected from the effluent treatment plant (ETP) of Nagaon Paper Mill, Kagajnagar, Assam (India). The dewatered sludge, as the name suggests, was collected from the ETP plant after the waste had passed through the sedimentation process and then partially dewatered by pumping. $\mathrm{CD}$ was obtained from a livestock farm near IIT, Guwahati campus, Assam (India) and FPW from Bhogali Jalpan (a traditional breakfast item maker), Guwahati, Assam (India). The percentages and physico-chemical properties of DS, CD and FPW in the different mixtures are reported in Table 1.

\section{Experiment}

Locally made round bamboo containers, each with a radius of $120 \mathrm{~mm}$ and depth of $90 \mathrm{~mm}$ enclosing a volume of $90.47 \times 10^{4} \mathrm{~mm}^{3}$, were filled with mixtures containing different percentages of DS, CD and FPW. There were three replicas of each treatment (Table 1). The containers were kept in the laboratory at room temperature and the total weight of substrate in each container was kept at $1.5 \mathrm{~kg}$. There was $10 \mathrm{~cm}$ of bedding in each container consisting of a mixture of hay (155 g), CD (375 g), banana leaves and tree leaves $(280 \mathrm{~g})$, which had been previously partially degraded over a period of two weeks. Approximately $50 \mathrm{~g}$ or $\sim 100-120$ earthworms (P. excavatus), consisting of both mature and juvenile individuals, were placed on the bedding and left to acclimatize to the new environment and then the next day the substrate was placed on top of the bedding.

$1.5 \mathrm{~kg}$ of five different mixtures of DS, CD and FPW was added to each of the containers and they are referred to as T1, T2, T3, T4 and T5, respectively. In addition there was a control for each mixture CT1, CT2, CT3, CT4 and CT5, respectively. The quantity of the substrate provided was based on the fact that the earthworms can consume half their body weight per day of substrate under favourable conditions (Haimi and Huhta 1987). The moisture level was maintained throughout the study period by periodically sprinkling tap water over the substrate. To pre-

Table 1 The weights and the initial characteristics of the different wastes in the compost.

\begin{tabular}{|c|c|c|c|}
\hline \multirow[b]{2}{*}{ Reactors/Parameters } & \multicolumn{3}{|c|}{ Waste materials } \\
\hline & $\begin{array}{l}\text { Dewatered sludge } \\
\text { (DS) }\end{array}$ & Cow dung (CD) & $\begin{array}{l}\text { Food processing } \\
\text { waste (FPW) }\end{array}$ \\
\hline T1 (kg) & 1.5 & - & - \\
\hline T2 (kg) & 1.0 & 0.24 & 0.26 \\
\hline T3 (kg) & 1.0 & 0.34 & 0.16 \\
\hline T4 (kg) & 1.0 & 0.41 & 0.09 \\
\hline T5 (kg) & 1.0 & 0.46 & 0.04 \\
\hline Moisture content (MC) (\%) & $71.2 \pm 1.2$ & $83.1 \pm 3.2$ & $9.2 \pm 2.6$ \\
\hline $\mathrm{pH}$ & $6.82 \pm 0.01$ & $7.20 \pm 0.03$ & $6.61 \pm 0.02$ \\
\hline Electrical conductivity (mmohs/cm) & $0.73 \pm 0.02$ & $1.21 \pm 0.02$ & $1.22 \pm 0.04$ \\
\hline Ash content (\%) & $43.1 \pm 1.4$ & $27.5 \pm 1.2$ & $6.6 \pm 0.4$ \\
\hline Total organic carbon (TOC) (\%) & $31.6 \pm 1.7$ & $40.3 \pm 2.1$ & $51.8 \pm 1.5$ \\
\hline Total nitrogen $(\mathrm{TN})(\mathrm{g} / \mathrm{kg})$ & $6.4 \pm 0.8$ & $15.1 \pm 1.1$ & $16.4 \pm 0.9$ \\
\hline Ammonical Nitrogen (NH4-N) (mg/kg) & $3.21 \pm 1.02$ & $4.62 \pm 1.21$ & $3.12 \pm 1.34$ \\
\hline Total phosphorous (TP) (g/kg) & $3.91 \pm 0.41$ & $0.62 \pm 0.12$ & $1.21 \pm 0.32$ \\
\hline Available phosphorus (AP) (g/kg) & $0.37 \pm 0.11$ & $0.22 \pm 0.09$ & $0.01 \pm 0.01$ \\
\hline Chemical oxygen demand (COD) (mg/kg) & $591 \pm 27$ & $145 \pm 16$ & $22736 \pm 341$ \\
\hline Biochemical oxygen demand (BOD) $(\mathrm{mg} / \mathrm{kg})$ & $370 \pm 41$ & $110 \pm 17$ & $16 \pm 8$ \\
\hline CO2 evolution (mg/g VS/day) & $8.72 \pm 0.84$ & $22.41 \pm 1.20$ & $10.74 \pm 0.59$ \\
\hline Oxygen uptake rate (OUR) (mg/g VS/day) & $18.9 \pm 0.5$ & $40.1 \pm 1.1$ & $1.0 \pm 0.1$ \\
\hline
\end{tabular}

European Journal of Environmental Sciences, Vol. 3, №. 1 
vent moisture loss, the bamboo containers were covered with gunny bags.

\section{Parameters measured}

About $110 \mathrm{~g}$ of wet substrate (free of earthworms, hatchlings and cocoons) were collected from the containers on day zero and on the 15th, 30th and 45th day of the composting period. Day zero is the day before earthworm inoculation. $10 \mathrm{~g}$ of the sample was used to measure soluble biochemical oxygen demand (BOD), chemical oxygen demand (COD), oxygen uptake rate (OUR) and $\mathrm{CO}_{2}$ production as described in Khwairakpam and Bhargava (2009a). Sub-samples were oven dried, ground to pass through a $0.2-\mathrm{mm}$ sieve and stored in plastic vials for further analysis: $\mathrm{pH}$ and conductivity were measured in $1: 10(\mathrm{w} / \mathrm{v})$ water suspensions using digital $\mathrm{pH}(\mu \mathrm{pH}$ system 361) and conductivity meters (VSI-04 Deluxe), ash content $\left(550{ }^{\circ} \mathrm{C}\right.$ for $2 \mathrm{~h}$ ) (loss on ignition), total nitrogen (TN) using the Kjeldahl method, ammonical nitrogen $\left(\mathrm{NH}_{4}-\mathrm{N}\right)$ and nitrate nitrogen $\left(\mathrm{NO}_{3}-\mathrm{N}\right)$ using KCL extraction (Tiquia and Tam 2000), total organic carbon (TOC) determined by Shimadzu (TOC-V $\mathrm{CSN}_{\text {N }}$ ) Solid Sample Module (SSM-5000A) and total and available phosphorus (TP and AP) using acid digestion and the stannous chloride method (APHA 2001). The $\mathrm{C} / \mathrm{N}$ value was calculated from the measured values of total organic carbon and nitrogen. In addition earthworm growth in terms of biomass and total mortality were measured at the end of every 15 th day of the experiment.

\section{Statistical analysis}

All the results are the means of three replicates. The results were statistically analyzed at 0.05 probability level using one way analysis of variance (ANOVA) and Tukey's HSD test as a post-hoc analysis to compare the means using Statistica software.

\section{Results and discussion}

\section{Moisture content}

In most treatments the moisture content increased during decomposition. The exceptions were T1, CT1 and T5. It is important that the moisture content is suitable for the earthworms and micro-organisms in the vermicomposting system and in this experiment it was $64-67 \%$ in most of the treatments. Lower moisture contents were recorded in T1 $(8 \%)$ and CT1 $(4 \%)$, which might be due to the nature of the raw waste material (100\% DS). The greatest changes in water content were recorded in $\mathrm{T} 2$ (15.7\%) and CT2 (17\%) at the end of 45 days (Table 1). The ideal moisture range for vermicomposting or vermiculture is 60-80\% (Neuhauser et al. 1988; Edwards 1998), which was achieved in this experiment. The variations in moisture content during the vermicomposting were significant $(\mathrm{P}<0.05)$.

\section{pH}

The value of $\mathrm{pH}$ increased in all the treatments. The greatest increase in $\mathrm{pH}$ was recorded in $\mathrm{T} 3$, where it increased from an initial value of 5.7 to 7.7 , followed by CT3 (5.7 to 7.1) and the lowest increase was recorded in CT1 (6.8 to 6.9) followed by CT2 (6.7 to 7.2) (Table 1). That is, the change in $\mathrm{pH}$ in all treatments indicated the compost became more alkaline and suitable for application to soil. Compost has a liming effect due to its richness in alkaline cations such as $\mathrm{Ca}, \mathrm{Mg}$ and $\mathrm{K}$, which were liberated from OM due to mineralization. Consequently, regular applications of compost maintain or enhance soil pH (Ouedraogo et al. 2001). Only in a few cases is a decrease in $\mathrm{pH}$ recorded after applying compost (Zinati et al. 2001). The change in $\mathrm{pH}$ during vermicomposting depends upon substrate, as different substrates may produce different intermediate organic acids (Gupta and Garg 2008). Similar observations are also recorded for vermicomposting by earlier workers (Hait and Tare 2010; Kaur et al. 2010). Earthworms selectively increase populations of catabolically more active microbes (Aira et al. 2007) therefore the degradation of short chain fatty acids and precipitation of calcium carbonate may be the cause of the increase in $\mathrm{pH}$ recorded in vermicomposting (Tognetti et al. 2005). Variations in $\mathrm{pH}$ were statistically significant $(\mathrm{P}<0.05)$.

\section{Electrical conductivity (EC)}

The release of different mineral salts in available forms may account for the increase in EC recorded in all the treatments. Greatest percentage change was recorded in T1 (59.2\%) and T2 (45.8\%) followed by CT1 (32.4\%) and the least in CT5 (4.5\%), CT4 (6.2\%) and CT3 (7.1\%), respectively (Table 1). A similar increase in EC is also reported by other authors (Suthar 2007; Gupta and Garg 2008; Yadav and Garg 2009). In a closed system there is an increase in mineral salts associated with the loss in terms of weight of organic matter, which may account for the increase in EC (Khwairakpam and Bhargava 2009a). Variations in EC were statistically significant $(\mathrm{P}<0.05)$.

\section{Ash content (\%)}

The high increase in ash content indicates that the organic material is being degraded during by the vermicomposting process. The highest increase in ash content was recorded after 30 days of vermicomposting. This shows that earthworms consumed the waste material and microbes were active during the decomposition process. The ash content is an important indicator of decomposition and mineralization of the substrate (Gupta et al. 2007; Gupta and Garg 2008; Khwairakpam and Bhargava 

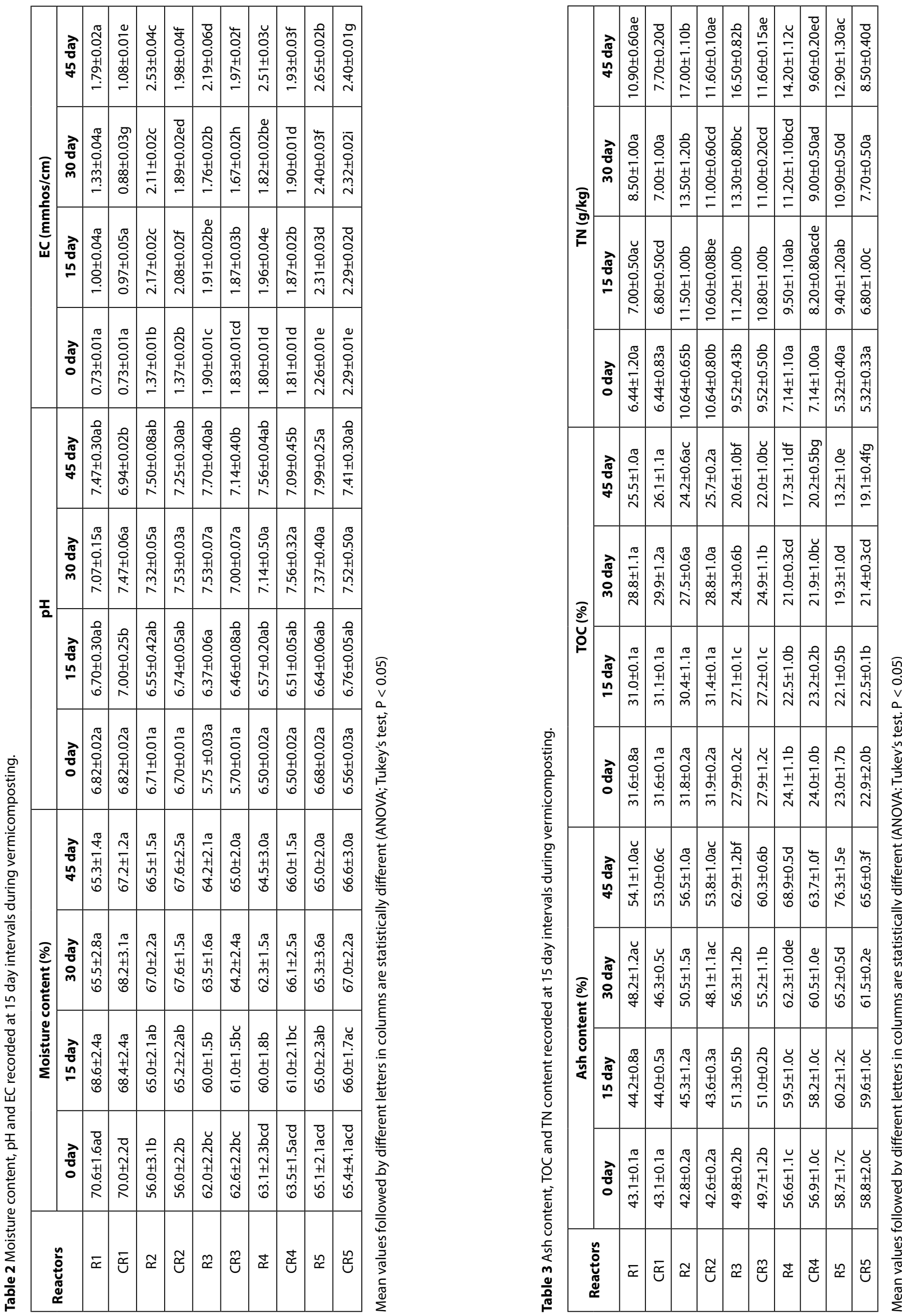

European Journal of Environmental Sciences, Vol. 3, No. 1 


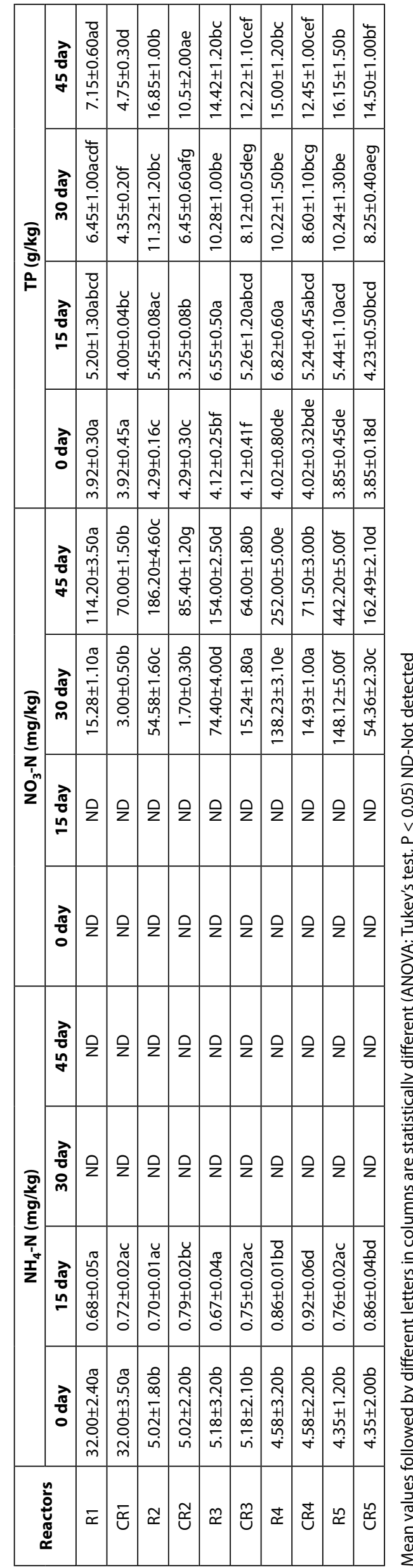

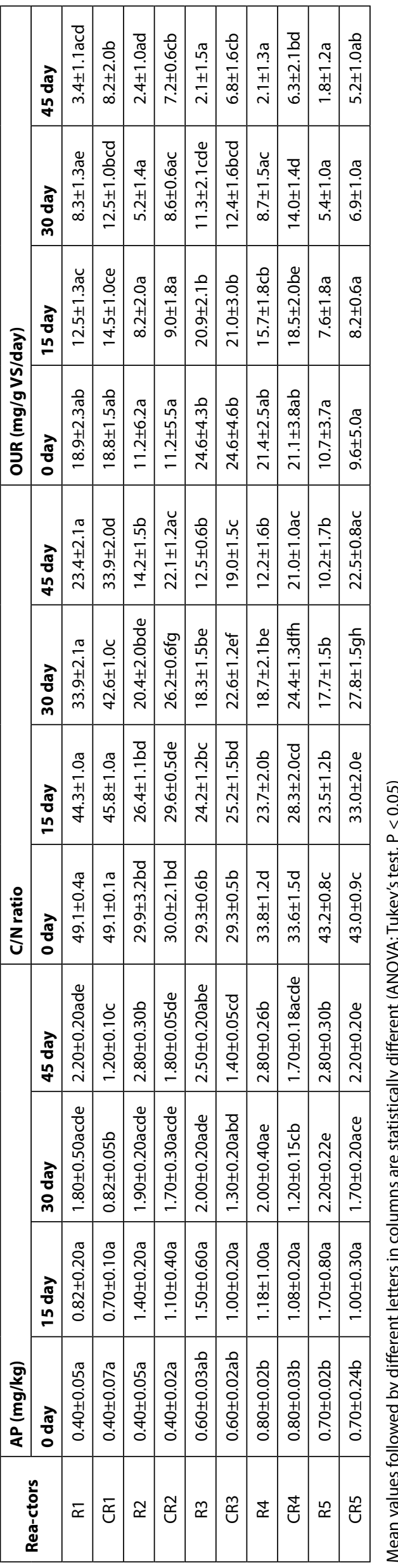


$2009 \mathrm{~b})$. The greatest increase in ash content was recorded in T2 (24.2\%), T5 (23.1\%) and T3 (20.8\%) and least in CT5 (10.4\%), CT4 (10.7\%) and CT3 (17.6\%), respectively (Table 2). Earlier workers also report an increase in ash content (Yadav and Garg 2009; Deka et al. 2011a). The variation in ash content was statistically significant $(\mathrm{P}<0.05)$.

\section{Total organic carbon (TOC)}

There was a decrease in organic carbon in all the treatments probably due to substrate mineralization, brought about by the metabolic activity of the earthworms and associated micro flora (Orozco et al. 1996). Final TOC was lower in vermicompost and compost as compared to the initial value. At the end of bioconversion period, a significant fraction of the TOC contained in the initial mixture was lost as $\mathrm{CO}_{2}$ (Elvira et al. 1996) possibly the result of the available carbon being used as a source of energy by the earthworms and microbes (Khwairakpam and Bhargava 2009b). The physical, biological and chemical environment of the waste is modified by the earthworms, which make the waste more suitable for colonization by microbial communities, which in turn results in loss of carbon (Suthar and Singh 2008). The greatest decrease in TOC was recorded in T5 (42.7\%) and CT3 (21.1\%) and least in T1 (19.4\%) and CT4 (15.8\%) (Table 2). These results are similar to those reported previously of between 20-43\% (Elvira et al. 1997) and up to 45\% (Kaviraj and Sharma 2003). Variation in TOC in the different treatments was statistically significant $(\mathrm{P}<0.05)$.

\section{Nitrogen content}

TN increased in all the treatments, possibly a result of the activity of earthworms, as reported by other authors (Suthar and Singh 2008). Earthworms also have a great effect on the transformation of nitrogen in manure, by enhancing nitrogen mineralization, which results in nitrogen being retained in the form of nitrates (Atiyeh et al. 2000). However, in general the final nitrogen content of compost is dependent on the initial nitrogen content in the waste. TN consists of the inorganic forms of nitrogen ammonium $\left(\mathrm{NH}_{4}-\mathrm{N}\right)$ and nitrate $\left(\mathrm{NO}_{3}-\mathrm{N}\right)$. The greatest TN was recorded in T5 (58.7\%) followed by T4 (49.7\%), T3 (43.2\%) and least in CT2 (8.2\%) followed by CT1 (16.3\%) and CT (17.9\%), respectively (Table 2$)$. Also using the same species of earthworm, earlier workers also report many fold increases in TN (Suthar and Singh 2008; Khwairakpam and Bhargava 2009a; Deka et al. 2011b). A decrease in $\mathrm{NH}_{4}-\mathrm{N}$ and corresponding increase in $\mathrm{NO}_{3}-\mathrm{N}$ was recorded during the final stages of the vermicomposting process (Table 3). Over the first 15 days there was a decrease in the amount of $\mathrm{NH}_{4}-\mathrm{N}$ $(98.8 \%)$. The greatest change of $98 \%$ was recorded in $\mathrm{T} 1$. This might be due to the loss of $\mathrm{NH}_{4}-\mathrm{N}$ as volatile ammonia at high $\mathrm{pH}$ values. There was a $1.8-7.4$ fold increase in $\mathrm{NO}_{3}-\mathrm{N}$ during the later stages of the composting process. Greatest change was recorded in T1 (7.4 fold). The difference in the various forms of nitrogen is due to immobilization/denitrification or both (Khwairakpam and Bhargava 2009a). ANOVA revealed that the differences are statistically significant $(\mathrm{P}<0.05)$.

\section{Phosphorus turnover}

Total phosphorus (TP) content was greater at the end of the composting process, probably because of mineralization of organic matter (Elvira et al. 1997). The greatest TP was recorded in T5 (76.1\%) followed by T2 (74.5\%) and CT5 (73.4\%), and the least in CT1 (17.4\%) followed by T1 $(45.1 \%)$ and CT2 (59.1\%), respectively (Table 4$)$. Similar results are reported by other workers who record the stimulating effect of earthworms on the availability of phosphorous in soil (Krishnamoorthy 1990; Kaviraj and Sharma 2003; Tognetti et al. 2005). Enzymes in the guts of earthworms have a stimulating effect on phosphate solubilizing bacteria (Satchell and Martin 1984). Available phosphorus (AP) is more important for plant maturation than plant growth (Yadav and Garg 2009). Addition of phosphorus to vermicompost also prevents the loss of nitrogen by the volatilization of ammonia (Yadav and Garg 2011). Vermicomposting is an efficient way of transforming unavailable forms of phosphorous into forms easily available to plants (Ghosh et al. 1999). Similar increases in AP were recorded in the vermicompost, with greatest increase recorded in T2 (85.7\%) (Table 5). The variation in $\mathrm{TP}$ was significant $(\mathrm{P}<0.05)$.

\section{C/N ratio}

The $\mathrm{C} / \mathrm{N}$ ratio is the most reliable indicator of the degree of decomposition and whether the compost is ready for field application. In general, the carbon content decreased and that of nitrogen increased during the decomposition process in all treatments. However, the $\mathrm{C} / \mathrm{N}$ ratio varies widely depending on the rate of decomposition (Subramanian et al. 2010). The final values of the $\mathrm{C} / \mathrm{N}$ ratio in all the containers were in the range of 10-23, which indicates an advanced degree of organic matter stabilization and a satisfactory degree of maturity of the organic waste (Senesi 1989) (Table 5). The greatest change was recorded in T5 (4.2 fold) followed by T4 (2.7 fold) and T3 (2.3 fold) and least in CT2 (1.3 fold) followed by CT1 (1.4 fold) and CT3 (1.5 fold), respectively. Earthworms digest long chain polysaccharides and enhance the colonization of the compost by microbes (Aira et al. 2007), which further accelerates the rate of organic matter degradation and nitrogen fixation (Garg and Kaushik 2005). This results in a greater decline in $\mathrm{C} / \mathrm{N}$ ratio in the vermicompost than in the compost. Some nitrogen is also added by the worms during vermicomposting in the form of mucus, nitrogenous excretory substances, hormones and enzymes (Hobson et al. 2005; Neuhauser 
et al. 1986). The decrease in the $\mathrm{C} / \mathrm{N}$ ratio recorded over time might also be attributed to the increase in the earthworm population (Ndegwa and Thompson 2000). Earthworms decompose the carbonaceous wastes efficiently and lower the $\mathrm{C} / \mathrm{N}$ ratio, which might account for lower $\mathrm{C} / \mathrm{N}$ ratio recorded in vermicompost than in compost. $\mathrm{C} / \mathrm{N}$ ratio varied significantly in all vermicompost and compost treatments $(\mathrm{P}<0.05)$.

\section{Rate of oxygen uptake (OUR)}

Initially the OUR recorded in all the treatments was high possibly due to the rapid growth of microbes. OUR is the most frequently used method for determining the biological activity of waste material (Gomez 2006). It measures compost stability by evaluating the amount of readily biodegradable organic matter still present in a sample based on the oxygen demand (Khwairakpam and Bhargava 2009b). The OUR was greatest during the active stage of composting, as microbes grow rapidly because there is an abundance of readily biodegradable substrate (Kalamdhad and Kazmi 2009). At the onset of the composting process large organic molecules are broken down into smaller, soluble ones and temporarily more substrate may become available. The decrease in OUR was greatest in T3 (11.3 fold) followed by T4 (10.1 fold) and T1 (5.5 fold) and least in CT2 (1.5 fold) followed by CT5 (1.8 fold) and CT1 (2.2 fold) (Table 5). Earlier researchers also record a decrease in OUR during the vermicomposting process (Khwairakpam and Bhargava 2009b). The changes in OUR were statistically significant $(\mathrm{P}<0.05)$.

\section{Rate of production of $\mathrm{CO}_{2}$}

The rate of production of $\mathrm{CO}_{2}$ was greatest during the initial stages of the composting process possibly due to a high level of microbial activity. The production of $\mathrm{CO}_{2}$ is the most direct way of determining the stability of the compost because it measures carbon that originates directly from the compost. Thus, the production of $\mathrm{CO}_{2} \mathrm{di}-$ rectly correlates with aerobic respiration, which is the best measure of aerobic biological activity (Khwairakpam and Bhargava 2009b). The greatest decrease in respiratory activity was recorded during the initial stages of composting. The greatest production of $\mathrm{CO}_{2}$ was recorded in T5 (6.7 fold) followed by T3 (5.6 fold) and T2 (4.8 fold), and least in CT1 (1.9 folds) followed by CT2 (2.7 fold) and CT4 (2.4 fold) (Table 6). Waste in the early stages of composting has a strong demand for $\mathrm{O}_{2}$ and produces large quantities of $\mathrm{CO}_{2}$ due to a great increase in the numbers of micro-organisms that develop on the abundance of easily biodegradable compounds in the raw material. For this reason, $\mathrm{O}_{2}$ consumption or $\mathrm{CO}_{2}$ production can be used as an indicator of the stability and maturity of the compost (Kalamdhad et al. 2008). All the variations in $\mathrm{CO}_{2}$ production were significant $(\mathrm{P}<0.05)$.

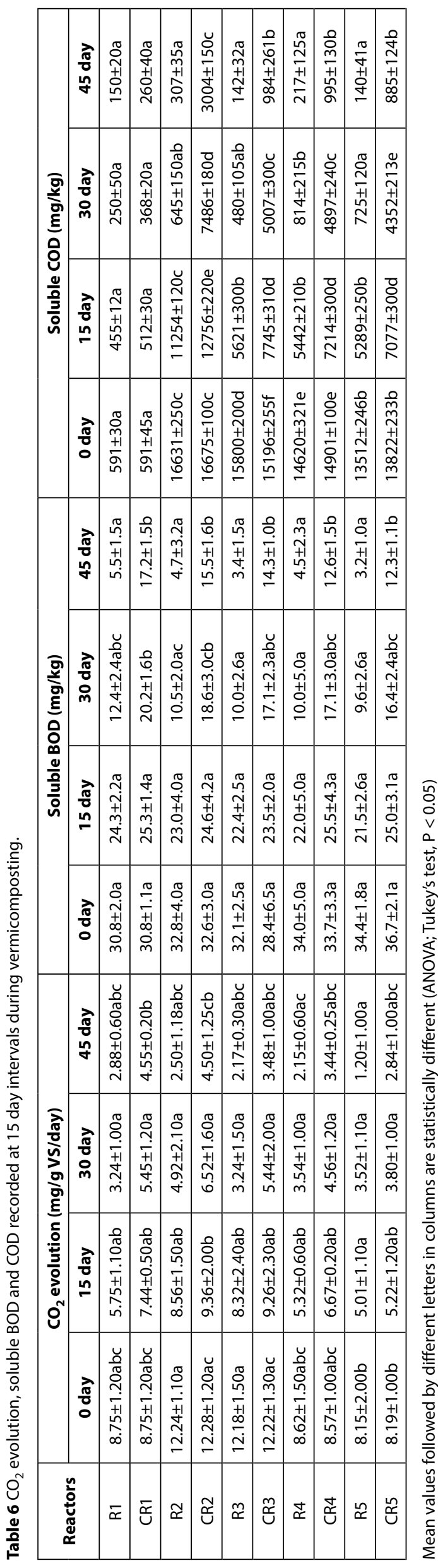

European Journal of Environmental Sciences, Vol. 3, No. 1 


\section{Soluble BOD and COD}

It is generally recognized that the percentage of readily biodegradable organic matter is an important determinant of compost quality. Only the $\mathrm{C} / \mathrm{N}$ ratio gives a clear indication of the stability of the compost because $\mathrm{O}_{2}$ consumption continues, which indicates the compost is still immature. In order to determine the $\mathrm{O}_{2}$ consumption it is necessary to measure soluble $\mathrm{BOD}$ and COD. When applying compost to soil for crop use, care should be taken because the biological processes will continue and can strip nutrients from soil even if the compost is stable (Wang et al. 2004). Hence it is important to monitor BOD. The decrease in BOD was greatest in T5 (10.7 fold) followed by T3 (9.3 fold) and T4 (7.5 fold), and least in CT1 (1.7 fold), CT3 (1.9 fold) and CT2 (2.1 fold) (Table 6). The greatest reduction in COD was recorded in T3 (111.2 fold), T5 (96.5 fold) and T4 (67.3 fold), and the least in CT1 (2.2 fold), T1 (3.9 fold) and CT2 (5.5 fold), respectively. The variations in $\mathrm{BOD}$ and $\mathrm{COD}$ at the end of the composting process were significant $(\mathrm{P}<0.05)$ in all the treatments.

\section{Growth and reproduction of earthworms}

After 45 days of earthworm activity the vermicompost was a dark brown colour and had an homogenous texture. The earthworm biomass increased in all the vermicomposts. Earthworm biomass increased in all the treatments except for $\mathrm{T} 1$, where there was a $5.5 \%$ reduction in biomass (Table 7). This may be due to the nature of substrate, which consisted of $100 \%$ dewatered sludge. The greatest increase in earthworm biomass was recorded in T5 (19.3\%) followed by T4 (16.6\%) and T3 $(10.7 \%)$, respectively. Cocoon production was greatest in T3 with 0.017 cocoons/worm/day followed by T2 $(0.015$ cocoons/worm/day) and T4 (0.014 cocoons/worm/day). Other researchers working with $P$. excavatus also report an increase in cocoons/worm/day (Knieriemen 1985; Reinecke et al. 1992; Suthar 2006; Khwairakpam and Bhargava 2009b; Deka et al. 2011b). The number of juveniles that hatched per $100 \mathrm{gm}$ of end product was quite high, with the greatest number of 90 recorded in $\mathrm{T} 5$ and least in T2 (28).

\section{Conclusions}

The end product after 45 days of vermicomposting was a dark brown colour and smelt of humus. P. excavatus effectively processed the organic wastes and produced an end product rich in TN and TP. The higher nutrient content, lower $\mathrm{C} / \mathrm{N}$ ratio and $\mathrm{EC}$, plus higher $\mathrm{pH}$ of the vermicompost indicates that vermicomposting is the better option for disposing of dewatered sludge from pulp and paper mills. Overall T5 proved to be the best combination for vermicomposting followed by T3, T2, $\mathrm{T} 4$ and $\mathrm{T} 1$, respectively. The low biomass of earthworms recorded in T1 may be due to the nature of the substrate, which consisted of $100 \%$ DS. However, the growth of earthworms was good in all the other treatments and best in T5. The results indicate that there is an inverse relationship between the growth rate and cocoon production by earthworms and the percentage of DS in the waste material.

\section{Acknowledgements}

The authors are very thankful to Dr. Nikhileshwar Sharma, Senior Manager, Nagaon Paper Mill, Kagajnagar for providing the dewatered sludge.

\section{REFERENCES}

Aira M, Monroy F, Dominguez J (2007) Earthworms strongly modify microbial biomass and activity triggering enzymatic activities during vermicomposting independently of the application rates of pig slurry. Sci Tot Environ 385: 252-261.

APHA (2001) Standard methods for the examination of water and wastewater. 17th edition, American Public Health Association, Washington, DC.

Atiyeh RM, Dominguez J, Subler S, Edwards CA (2000) Changes in biochemical properties of cow manure during processing by earthworms (Eisenia andrei, Bouché) and the effects on seedling growth. Pedobiologia 44: 709-724.

Chaudhuri PS (2005) Vermiculture and vermicomposting as biotechnology for conversion of organic wastes into animal protein and organic fertilizer. Asian J Microbiol Environ Sci 7: 359-370.

Table 7 Live biomass production of earthworms in different treatments.

\begin{tabular}{|c|c|c|c|c|c|}
\hline \multirow{2}{*}{ Vermireactor } & \multicolumn{2}{|c|}{ Mean weight of Earthworms (g) } & \multirow{2}{*}{$\begin{array}{c}\text { Live biomass } \\
\text { (\% change) }\end{array}$} & \multirow{2}{*}{ Coocons/worm/day } & $\begin{array}{c}\text { No. of Juveniles } \\
\text { hatched/100 g }\end{array}$ \\
\cline { 2 - 5 } & Initial & Final & $-5.6 \pm 3.6 \mathrm{ab}$ & $0.004 \pm 0.001 \mathrm{ae}$ & $30 \pm 1 \mathrm{a}$ \\
\hline T1 & 50 & $55 \pm 1 \mathrm{bc}$ & $10 \pm 1.7 \mathrm{ab}$ & $0.015 \pm 0.005 \mathrm{bc}$ & $28 \pm 2 \mathrm{~b}$ \\
\hline T2 & 50 & $56 \pm 3 \mathrm{~cd}$ & $12 \pm 6 \mathrm{bc}$ & $0.017 \pm 0.002 \mathrm{c}$ & $50 \pm 1 \mathrm{~cd}$ \\
\hline T3 & 50 & $60 \pm 2 \mathrm{de}$ & $20 \pm 4 \mathrm{~cd}$ & $0.014 \pm 0.003 \mathrm{db}$ & $55 \pm 3 \mathrm{~d}$ \\
\hline T4 & 50 & $62 \pm 1.5 \mathrm{e}$ & $24 \pm 3 \mathrm{~d}$ & $0.009 \pm 0.001 \mathrm{ebd}$ & $90 \pm 4 \mathrm{e}$ \\
\hline
\end{tabular}


Deka H, Deka S, Baruah CK, Das J, Hoque S, Sarma NS (2011a) Vermicomposting of distillation waste of citronella plant (Cymbopogon winterianus Jowitt.) employing Eudrilus eugeniae. Biores Tech 102: 6944-6950.

Deka H, Deka S, Baruah CK, Das J, Hoque S, Sarma H, Sarma NS (2011b) Vermicomposting potentiality of Perionyx excavates for recycling of waste biomass of java citronella - an aromatic oil yielding plant. Biores Tech 102: 11212-11217.

Edwards CA, Bohlen PJ (1996) Biology and Ecology of Earthworm. 3rd ed. Chapman and Hall, New York, London.

Edwards CA, Dominguez J, Neuhauser EF (1998) Growth and reproduction of Perionyx excavatus (Perr.) Megascolecidae as factors in organic waste management. Biol Fertil Soils 27: 155-161.

Edwards CA (1998) The use of earthworms in the breakdown and management of organic wastes. In: Edwards, CA (ed.) Earthworm Ecology. CRC Press, Boca Raton, FL, pp. 327-354.

Elvira C, Domínguez J, Mato S (1996) The growth and reproduction of Lumbricus rubellus and Dendrobaena rubida in cow manure mixed cultures with Eisenia Andrei. Appl Soil Ecol 5: 97-103.

Elvira C, Sampedro L, Benitez E, Nogales R (1998) Vermicomposting of sludges from paper mill and dairy industries with Eisenia andrei: a pilot scale study. Biores Tech 63: 205-211.

Elvira C, Sampedro L, Dominguez J, Mato S (1997) Vermicomposting of wastewater sludge from paper-pulp industry with nitrogen rich material. Soil Bio Biochem 29: 759-762.

Gajalakshmi S, Ramasamy EV, Abbasi SA (2001) Assessment of sustainable vermiconversion of water hyacinth at different reactor efficiencies employing Eudrilus engeniae Kingburg. Biores Tech 80: 131-135.

Ghosh M, Chattopadhyay GN, Baral K (1999) Transformation of phosphorus during vermicomposting. Biores Tech 69: 149-154.

Gomez RB, Lima FV, Ferrer AS (2006) The use of respiration indices in the composting process: a review. Waste Manag Res 24 $37-47$.

Gupta R, Garg VK (2008) Stabilization of primary sewage sludge during vermicomposting. J Hazard Mater 153: 1023-1030.

Gupta R, Mutiyar PK, Rawat NK, Saini MS, Garg VK (2007) Development of a water hyacinth based vermireactor using an epigeic earthworm Eisenia foetida. Biores Tech 98: 2605-2610.

Garg VK, Kaushik P (2005) Vermistabilization of textile mill sludge spiked with poultry droppings by an epigeic earthworm Eisenia foetida. Biores Tech 96: 1063-1071.

Haimi J, Huhta V (1987) Comparison of composts produced from identical wastes by vermistabilization and conventional composting. Pedobiologia 30: 137-144.

Hait S, Tare V (2010) Vermistabilization of primary sewage sludge. Biores Tech 102: 2812-2820.

Hobson AM, Frederickson J, Dise NB (2005) $\mathrm{CH}_{4}$ and $\mathrm{N}_{2} \mathrm{O}$ from mechanically turned windrow and vermicomposting systems following in-vessel pretreatment. Waste Manag 25: 345-352.

Hue NV, Liu J (1995) Predicting compost stability. Comp Sci and Utili 3: 8-15.

Kalamdhad AS, Pasha M, Kazmi AA (2008) Stability evaluation of compost by respiration techniques in a rotary drum composter. Resour Conserv Recycl 52: 829-834.

Kalamdhad AS, Kazmi AA (2009) Effects of turning frequency on compost stability and some chemical characteristics during rotary drum composting. Chemosphere 74: 1327-1334.

Kale RD, Bano K, Krishnamoorthy RV (1982) Potential of Perionyx excavatus for utilization of organic wastes. Pedobiologia 23: 419-425.
Kaur A, Singh J, Vig AP, Dhaliwal SS, Rup PJ (2010) Cocomposting with and without Eisenia fetida for conversion of toxic paper mill sludge to a soil conditioner. Biores Tech 101: 8192-8198.

Kaushik P, Garg VK (2003) Vermicomposting of mixed solid textile mill sludge and cow dung with the epigeic earthworm Eisenia foetida. Biores Tech 90: 311-316.

Kaviraj SS, Sharma S (2003) Municipal solid waste management through vermicomposting employing exotic and local species of earthworms. Biores Tech 90: 169-173.

Khwairakpam M, Bhargava R (2009a) Bioconversion of filter mud using vermicomposting employing two exotic and one local earthworm species. Biores Tech 100: 5846-5852.

Khwairakpam M, Bhargava R (2009b) Vermitechnology for sewage sludge recycling. J Hazard Mater 161: 948-954.

Knieriemen D (1985) Biomass production through the propagation of thermophilic earthworms. In: Bittner A (ed.) Animal Research and Development. Hauser, Tübingen, Germany, pp. 112-127.

Krishnamoorthy RV (1990) Mineralization of phosphorous by faecal phosphatase of some earthworms of Indian tropica. Proc Indian Acad Sci (Animal Sciences) 99: 509-518.

Maboeta MS, Rensburg VL (2003) Vermicomposting of industrially produced wood chips and sewage sludge using E. foetida. Ecotoxicol Environ Safety 56: 256-270.

Ndegwa PM, Thompson SA (2000) Effect of C-to-N ratio on vermicomposting of biosolids. Biores Tech 75: 7-12.

Ndegwa PM, Thompson SA (2001) Integrating composting and vermicomposting the treatment and bioconversion of biosolids. Biores Tech 76: 107-112.

Neuhauser EF, Loehr RC, Malecki MR (1988) The potential of earthworms for managing sewage sludge. In: Edwards CA, Neuhauser EF (eds) Earthworms in Waste and Environmental Management. SPB Academic Publishing, The Hague, pp. 9-20.

Orozco SH, Cegarra J, Trujillo LM, Roig A (1996) Vermicompostsing of coffee pulp using the earthworm Eisenia fetida: effects on $\mathrm{C}$ and $\mathrm{N}$ contents and the availability of nutrients. Biol Fert Soils 22: 162-166.

Ouedraogo E, Mando A, Zombre NP (2001). Use of compost to improve soil properties and crop productivity under low input agricultural system in West Africa. Agriculture Ecosyst Environ 84: 259-266.

Reinecke AJ, Viljoen SA, Saayman RJ (1992) The suitability of Eudrilus eugeniae, Perionyx excavatus and Eisenia fetida (Oligochaeta. for vermi-composting in Southern Africa in terms of their temperature requirements. Soil Biol Biochem 24: $1295-1307$.

Suthar S (2006) Potential utilization of Guar gum industrial waste in vermicompost production. Biores Tech 97: 2474-2477.

Satchell JE, Martin K (1984) Phosphate activity in earthworm faeces. Soil Biol Biochem 16: 191-194.

Senesi N (1989) Composted materials as organic fertilizers. Sci Tot Environ 81/82: 521-524.

Singh NB, Khare AK, Bhargava DS, Bhattacharya S (2005) Effect of initial substrate $\mathrm{pH}$ on vermicomposting using Perionyx excavatus (perrier), 1872. Appl Ecol Environ Res 4: 85-97.

Subramanian S, Sivarajan M, Saravanapriya S (2010) Chemical changes during vermicomposting of sago industry solid wastes. J Hazard Mater 179: 318-322.

Suthar S (2007) Vermicomposting potential of Perionyx sansibaricus (Perrier.) in different waste materials. Biores Tech 98: 1231-1237. 
Suthar S (2008) Bioconversion of post harvest crop residues and cattle shed manure into value-added products using earthworms Eudrilus eugeniae (Kinberg). Ecol Eng 32: 206-214.

Suthar S, Singh S (2008) Feasibility of vermicomposting in biostabilization sludge from a distillery industry. Sci Tot Environ 393: 237-243.

Tiquia SM, Tam NFY (2000) Fate of nitrogen during composting of chicken litter. Environ Poll 110: 535-541.

Tognetti C, Laos F, Mazzarino MJ, Hernandez MT (2005) Composting vs. vermicomposting: a comparison of end product quality. Comp Sci Utility 1: 6-13.
Wang P, Changa CM, Watson ME, Dick WA, Chen Y, Hoitink HAJ (2004) Maturity indices for composted dairy and pig manures. Soil Biol Biochem 36: 767-776.

Yadav A, Garg VK (2011) Recycling of organic wastes by employing Eisenia fetida. Biores Tech 102: 2874-2880.

Yadav A, Garg VK (2009) Feasibility of nutrient recovery from industrial sludge by vermicomposting technology. J Hazard Mater 168: 262-266.

Zinati GM, Li YC, Bryan HH (2001). Utilization of compost increases organic carbon and its humin, humic and fulvic acid fractions in calcareous soil. Comp Sci Util 9: 156-162. 